\title{
Effect of Vitamin A and Vitamin C on Physiological Parameters of Males in Age Group 18 To 25 Years
}

\author{
Pooja Johri and Anuradha Lehri
}

\begin{abstract}
Aim: Effect of Vitamin A and Vitamin C on Physiological Parameters of Males in Age Group 18 To 25 Years. Method: 50 vitamin deficient males in the age group 18 to 25 years of age group were studied. The subjects were given recommended dose of the vitamins in the form of carrots and tomatoes daily and their physiological status was observed in terms of the following parameters: BMI, Blood Pressure, Weight and Hemoglobin over a period of forty days. Results: There was no significant change in BMI, Blood Pressure and weight after supplementation of vitamins. Vitamin supplementation however, increased significantly the hemoglobin content in these individuals. Conclusion: it was conclude that vitamin A and Vitamin $\mathrm{C}$ have no effect on BMI, Blood Pressure and weight but there is an increase in hemoglobin.
\end{abstract}

\author{
Pooja Johri \\ $\mathrm{PhD}$ Scholar \\ Department of Sports Science \\ Punjabi University, Patiala (India) \\ E-mail: johri_pooja@yahoo.com \\ Anuradha Lehri \\ Assistant Professor \\ Department of Sports Science \\ Punjabi University, Patiala (India)
}

\author{
Key Words: Vitamin A, Vitamin C, \\ BMI, Hemoglobin
}

DOI: $10.18376 /$ jesp/2017/v13/i2/111284

\section{Introduction}

Vitamins are derived from food and are essential to keep the body healthy and the mind alert. Although they do not provide energy or make up our cells or organs, without them the body cannot carry out many of the chemical processes it needs. Vitamins interact with other nutrients in processes such as metabolism, digestion and developing blood cells and some vitamins are said to slow down the ageing process, prevent cancerous cells attacking the body and strengthen the immune system. Recommended Dietary Allowance (RDA) for Vitamin C is $45-60 \mathrm{mg}$ per day for men above 18 years of age and RDA for vitamin A is 5000IU (http://www.anyvitamins.com/rda.htm). RDA for Vitamin A is Carrots (100 g) consists (334\% of RDA) of Vitamin $\mathrm{A}$ and $10 \%$ of RDA for Vitamin C. (http://www.healthaliciousness.com/nutritionfacts/nutritioncomparison.php?o $=11124 \& \mathrm{t}=11124 \& \mathrm{~h}=11960$ $\& \mathrm{~s}=100 \& \mathrm{e}=61.00 \& \mathrm{r}=15) .100 \mathrm{~g}$ of tomatoes contain $210 \%$ of RDA for vitamin $\mathrm{C}$.In a cross sectional study of children in northeast Thailand, serum retinol was found to be positively associated with serum iron and ferritin as reported by Bloem et. al (1989). Other studies have found a significant correlation between serum retinol and hemoglobin concentration by Mejia et. al (1977). Among Indian preschool children, hemoglobin values were found to be lower in those who had serum retinol below $20 \mu \mathrm{g} / \mathrm{dL}$ compared with those with normal levels as reported by Mohanram in (1977). Vitamin A and Vitamin C supplementation of deficient children resulted in a significant increase in hemoglobin, hematocrit, and serum iron. The present study involves the role of $\beta$-carotene source of Vitamin A and lycopene source of Vitamin $\mathrm{C}$ on physiological parameters of males in the age group (18-25 years), students of Bhojia Institute of Life Sciences. 


\section{Materials and Methods}

The fifty $(n=50)$ male students $(18-25$ years of age)studying in Bhojia Institute of Life Sciences ,situated at Bhud, Baddi, Himachal Pradesh, who were residing as paying guests in the neighbouring area were selected for the study. Their diet was evaluated by a three day recall method with the help of a questionnaire. These students were found to be deficient in their daily intake of Vitamin A and Vitamin $\mathrm{C}$ less than the recommended value as calculated by Dine software.The students were examined physiologically for the following parameters before treatment. These students were given $30 \mathrm{~g}$ of carrots and $50 \mathrm{~g}$ of tomatoes everyday and then their following physiological parameters were determined after every 10 days interval for 40 days.

1.Basal Mass Index (BMI): The height was measured by an anthropometric rod in $\mathrm{m}$. The weight was determined in kgs by weighing machine. BMI was calculated as follows: $\mathrm{BMI}=$ weight $/(\text { height })^{2}$

2.Blood Pressure (B.P.): B.P. was measured by syphgmanometer in $\mathrm{mm} \mathrm{Hg}$ of mercury by standardized method (Godkar2003).

3.Hemoglobin: Blood was taken by needle prick and hemoglobin was determined by Sahli's hemometer (Godkar2003).

The data was analyzed statistically by SPSS for Windows (version 11.5). Statistical methods used were ANOVA. $P<0.05$ was considered significant.

\section{Results and Discussion}

The mean BMI of the boys at the start of the experiment was $22.6 \pm 4.1$, after ten days BMI of the boys was $22.3 \pm 3.8$, after 20 days of administration BMI was $21.7 \pm 3.9$, similarly after 30 and 40 days of supplementation it was $22.0 \pm 3.7$ and $21.6 \pm 3.6$; means no significant change in BMI was observed. The mean Systolic Blood Pressure of the boys at the start of the experiment was $128.7 \pm 15.6$, after ten days Systolic Blood Pressure of the boys was $127.0 \pm 13.8$, after 20 days of administration Systolic Blood Pressure was $123.0 \pm 3.9$, similarly after 30 and 40 days of supplementation Systolic Blood Pressure was $120.9 \pm 2.3$ and $121.9 \pm 1.5$; means no significant change in Systolic Blood Pressure was observed. The mean Diastolic Blood Pressure of the boys at the start of the experiment was $83.4 \pm 13.8$, after ten days Diastolic Blood Pressure of the boys was $87.9 \pm 7.8$, after 20 days of administration Diastolic Blood Pressure was $85.6 \pm 3.1$, similarly after 30 and 40 days of supplementation Diastolic Blood Pressure was $83.4 \pm 1.5$ and $82.4 \pm 2.3$; means no significant change in Diastolic Blood Pressure was observed. The mean Haemoglobin of the boys at the start of the experiment was $13.8 \pm 0.7$, after ten days Haemoglobin of the boys was $14.3 \pm 0.6$, after 20 days of administration Systolic Blood Pressure was $123.0 \pm 3.9$, similarly after 30 and 40 days of supplementation Haemoglobin was $15.0 \pm 0.7$ and $15.2 \pm 0.7$; means significant change in Haemoglobin was observed. There was no significant change in BMI, Diastolic, Systolic blood pressure and weight but there was a significant increase in hemoglobin in 40 days of supplementation of Vitamin A and Vitamin C. Similar results were observed in the research carried by Ardekani and Ardekani(2007) on giving the supplementation of Vitamin C. Vitamin A supplementation did not have any effect on weight Oji et.al(2001).

\section{Conclusion}

From the above discussions we conclude that vitamin $\mathrm{A}$ and Vitamin $\mathrm{C}$ have no effect on BMI, Blood Pressure and weight but there is an increase in hemoglobin. The ability of vitamin $\mathrm{C}$ to support $\mathrm{Hb}$ production can be linked to effects of vitamin $\mathrm{C}$ on the metabolism of iron. The restriction of iron delivery from the tissues for erythropoiesis has been documented as a common feature of patients with renal disease and is frequently manifested as hypochromic reticulocytes or hypochromic red blood cells as reported by Brugnara in 1998. Smith et. al in (1980) were of the opinion that Vitamin C could improve red cell production by mobilizing storage iron, including especially that portion of tissue iron that accumulates as hemosid-erin. My results justify investigation of the relation between vitamin A and $\mathrm{C}$ and iron parameters (total $\mathrm{Hb}$ ) since these vitamins may mobilize storage iron for erythropoiesis. 
Journal of Exercise Science \& Physiotherapy, Vol. 13, No. 2, 2017

ISSN: $0973-2020$ (Print) I I OR Impact Factor = 5.23 UGC Approved [Journal No.7485] ISSN: 2454-6089 (online)

Table 1. Effect of Vitamin A and Vitamin C on physiological parameters

\begin{tabular}{|c|c|c|c|c|c|}
\hline Parameter & Day 0 & Day 10 & Day 20 & Day 30 & Day 40 \\
\hline Weight (Kg) & $\begin{array}{c}71.6 \pm \\
16.0\end{array}$ & $\begin{array}{c}70.3 \pm \\
15.2\end{array}$ & $\begin{array}{c}70.0 \pm \\
13.8\end{array}$ & $\begin{array}{c}70.3 \pm \\
14.7\end{array}$ & $\begin{array}{c}69.3 \pm \\
14.1\end{array}$ \\
\hline BMI $\left(\mathrm{Kg} \mathrm{M}^{-2}\right)$ & $22.6 \pm 4.1$ & $22.3 \pm 3.8$ & $\begin{array}{c}21.7 \pm \\
3.9 \\
\end{array}$ & $\begin{array}{c}22.0 \pm \\
3.7\end{array}$ & $\begin{array}{c}21.6 \pm \\
3.6\end{array}$ \\
\hline $\begin{array}{l}\text { Diastolic Pressure } \\
(\mathrm{MmHg})\end{array}$ & $\begin{array}{c}83.4 \pm \\
13.8\end{array}$ & $87.9 \pm 7.8$ & $\begin{array}{c}85.6 \pm \\
3.1\end{array}$ & $\begin{array}{c}83.4 \pm \\
1.5\end{array}$ & $\begin{array}{c}82.4 \pm \\
2.3 \\
\end{array}$ \\
\hline $\begin{array}{l}\text { Systolic Pressure } \\
(\mathrm{MmHg})\end{array}$ & $\begin{array}{c}128.7 \pm \\
15.6\end{array}$ & $\begin{array}{c}127.0 \pm \\
13.8\end{array}$ & $\begin{array}{c}123.0 \pm \\
3.9\end{array}$ & $\begin{array}{c}120.9 \pm \\
2.3\end{array}$ & $\begin{array}{c}121.9 \pm \\
1.5\end{array}$ \\
\hline Hemoglobin( $\left.\mathrm{GDI}^{-1}\right)$ & $13.8 \pm 0.7$ & $14.3 \pm 0.6$ & $\begin{array}{c}14.6 \pm \\
0.7\end{array}$ & $\begin{array}{c}15.0 \pm \\
0.7\end{array}$ & $\begin{array}{c}15.2 \pm \\
0.7\end{array}$ \\
\hline
\end{tabular}

Table 2: Testing of level of significance of the supplementation of Vitamin A and Vitamin C on physiological parameters

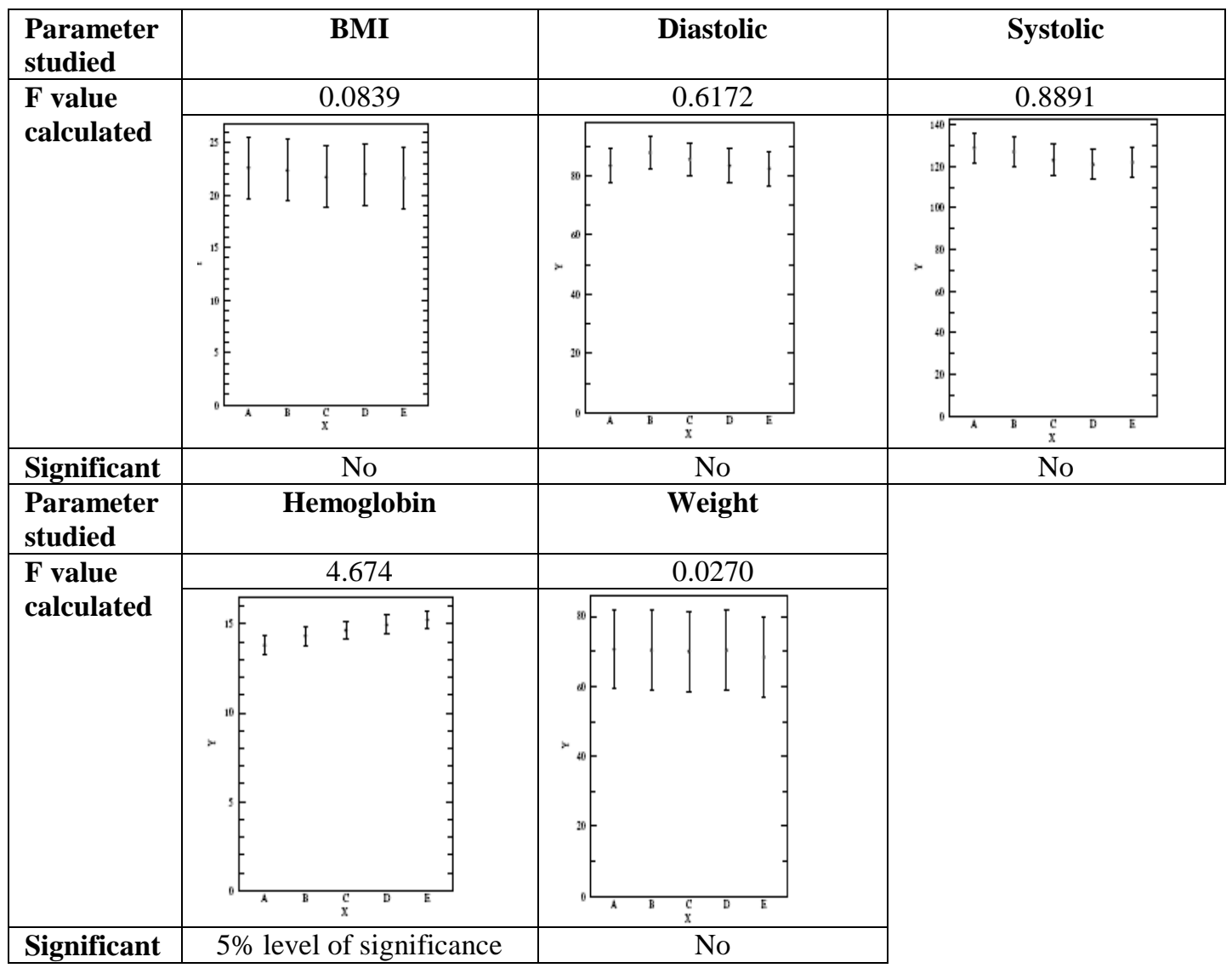




\section{Where: A: Day 0 \\ D: Day 30 \\ B: Day 10 \\ E: Day 40}

Degrees of freedom between groups: 4

Table value at $5 \%$ level of significance:

\subsection{6}

\section{C: Day 20}

\section{Degrees of freedom within groups: 30}

\section{References}

Ardekani M.A \& A.S Ardekani (2007). Effect of vitamin C on blood glucose, serum lipids \& serum insulin in type 2 diabetes patients, Indian J Med Res 126: 471-474.

Bloem MW, Wedel M, Egger RJ, et al. Iron metabolism and vitamin A deficiency in children in northeast Thailand. Am J Clin Nutr 1989; 50:332338 6.

Brugnara C. Use of reticulocyte cellular indices in the diagnosis and treatment of hematological disorders. Int J Clin Lab Res. 1998;28:1-11.

Godkar P.B .(2003).Textbook of Medical Laboratory Technology, Bhalani Publishing house, Mumbai,Page 707-719.

Mejia LA, Hodges RE, Arroyave G, et al. Vitamin A deficiency and anemia in Central American children. Am J Clin Nutr 1977; 30:11751184

Mohanram M, Kulkarni KA, Reddy V. Hematological studies in vitamin A deficient children. Int J Vitam Res 1977; 47:389393

Oji C.K. A. Coutsoudis, L. Kuhn,K. Pillay, A. Mburu, Z.Stein, and H. Coovadia (2001). Effects of Vitamin A Supplementation during Pregnancy and Early Lactation on Body Weight of South African HIVinfected Women, J Health Popul Nutr; 19(3):167-176.

Smith $\mathrm{CH}$, Bidlack WR. Interrelationship of dietary ascorbic acid and iron on the tissue distribution of ascorbic acid, iron and copper in female guinea pigs. J Nutr. 1980; 110:1398-408 